\title{
OXYGEN TENSION OF TISSUES BY THE POLAROGRAPHIC METHOD. I. INTRODUCTION : OXYGEN TENSION AND BLOOD FLOW OF THE SKIN OF HUMAN EXTREMITIES
}

\author{
By HUGH MONTGOMERY AND ORVILLE HORWITZ \\ (From the Peripheral Vascular Section of the Robinette Foundation, Medical Clinic, \\ Hospital of the University of Pennsylvania, Philadelphia)
}

(Submitted for publication February 22, 1950; accepted, May 29, 1950)

\section{INTRODUCTION}

Knowledge of tissue oxygen tension, if simultaneous measurements of blood flow are available, can greatly facilitate the study of tissue oxygen supply, utilization, and extraction from the blood. In the past, studies of oxygen content of arterial and of venous blood measured rates of oxygen utilization by those organs whose rates of circulation could be measured simultaneously. However, these instances were few and only gross changes of $\mathrm{O}_{2}$ tension in the tissues could be estimated. This method proved impracticable for use in intact skin because of the impossibility of obtaining representative samples of venous blood.

Clinically the estimation of altered $\mathrm{O}_{2}$ tension in intact skin of limbs has largely depended upon the changes in color resulting from different degrees of oxygen saturation of the hemoglobin in the small vessels. Such an estimate of $\mathrm{O}_{2}$ tension in skin is not only an extremely rough approximation, but is on occasion wholly erroneous. The cherry-red skin of the very ischaemic foot, termed "rubor on dependence," has a low $\mathrm{O}_{2}$ tension. Starr (1) has shown that the cyanotic color of extremely ischaemic skin can be changed to a pink color by exposing the limb to high concentrations of oxygen, with little resulting therapeutic effect. We have demonstrated extremely low $\mathrm{O}_{2}$ tension in the skin of normal hands made bright pink by local chilling $\left(0^{\circ}-10^{\circ}\right.$ C. $)$. The color, in this case, is not an estimate of skin $\mathrm{O}_{2}$ tension but only of oxygen concentration in its vessels.

Prior to the work of Davies and Brink (2) on the microelectrode, several methods had been employed to estimate oxygen concentrations in animal tissues, but none had proved satisfactory. Pflüger's (3) first method depended upon the measurement of oxygen in fluids derived from the organs, and was superseded by measuring the partial pressure of different gases equilibrated against these fluids. Strassburg (4) and Krogh $(5,6)$ refined the second of these methods. Verzár (7) calculated the $\mathrm{O}_{2}$ tension in tissues of organs from estimations of oxygen saturation of arterial blood and of blood within veins leaving the organs. Pietro (8) and Tobieson (9) measured tensions of gases in depots of gas injected into body cavities, canals, and subcutaneous areas. Campbell, in his review of the literature in 1931, concluded that the nearest approach to a satisfactory method for measuring $\mathrm{O}_{2}$ tension in intact tissue was the one in which gas bubbles were introduced into tissue, allowed to come to equilibrium with respect to oxygen, and the gas withdrawn and analyzed (10).

In 1942 Davies and Brink (2) came to the conclusion that the gas bubble technique, though the best up to that time, was far from satisfactory. It cannot measure rapid changes, or $\mathrm{O}_{2}$ tension in small areas. They briefly recounted the development of the platinum electrode for measurement of oxygen in solutions (11-15), and in green leaves (16), and designed two types of platinum electrodes for use in animal tissues $(17,18)$. One was a recessed tip electrode which could be calibrated in known solutions of oxygen, but had the disadvantages of slow "recovery" in use, and, as we have learned, of difficulty in cleaning after use in tissue. The other was an open type electrode which recovered rapidly and was easily cleaned, but gave only relative values. Hodes and Larrabee (19) used the open type electrode to measure direction of change of $\mathrm{O}_{2}$ tension in the intact skin of the human forearm. They demonstrated moderate increases in galvanometric deflections when skin was heated, great increases when oxygen was breathed, and decreases to zero when the circulation to the part was arrested. They demonstrated no linear relationship between $\mathrm{O}_{2}$ tension and current in skin, did not know what 
caused the changes with temperature, and had no way to calibrate the electrode to derive even semiquantitative results.

The method herein presented involves the use of a modified form of the free-tip electrode of Davies and Brink. Preliminary results were reported in 1948 (20). Efforts at calibration to allow quantitative expression of results as pressure of $\mathrm{O}_{2}$ in $\mathrm{mm}$. $\mathrm{Hg}$ have proved fairly successful. Day-to-day calibrations of some electrodes varied little, and these electrodes have been used in skin measurements. Other experiments of a more general nature do not require as well calibrated electrodes. The method is still under development, but we believe that it yields quantitative data on oxygen present in skin, and opens the way for in situ descriptions of oxygen metabolism in skin. A reasonably quantitative method for measuring cutaneous circulation (21) makes the interpretation of results easier. Skin $\mathrm{O}_{2}$ tensions measured under a variety of physiological and pathological conditions are reported.

\section{METHOD}

Apparatus. The electrodes and circuit used were based on the same principles as those utilized by Davies and Brink. Platinum in a circuit having a fixed, low voltage, reduces oxygen and the resultant current is proportional to the oxygen present in solution. Details of construction indicate our modifications.

The electrode was made of $0.2 \mathrm{~mm}$. platinum wire, soda lime glass tubing having $3 \mathrm{~mm}$. O.D. and $1.5 \mathrm{~mm}$. I.D., and mercury. Tubing was cut into $10 \mathrm{~cm}$. sections and the ends flamed to smoothness. The center of each section was brought to white heat while rotating at the tip of a gas flame $1 \mathrm{~cm}$. long by $0.5 \mathrm{~cm}$. wide. The cool ends were pulled to produce a narrowed portion $1 \mathrm{~cm}$. in length having an inside diameter just sufficient to admit the wire. A $10 \mathrm{~cm}$. length of the wire was held at its ends by forceps, flamed to clean and straighten it, and placed in a section of the tubing. The section was held by the fingers at each end, each of its two shoulders (narrowing points near center of section of tubing) was successively presented to the tip of a $0.5 \times 0.2 \mathrm{~cm}$. gas flame and the section of tubing was rotated and pulled. As soon as the shoulder melted upon the wire it was withdrawn from the flame. Scissors were used to cut through the glass-coated wire $5 \mathrm{~mm}$. from each new shoulder, thus forming two electrodes having tips approximately 0.4 $\mathrm{mm}$. in diameter. The points were ground while rotating at a $45^{\circ}$ angle on a Hard Arkansas whetstone. The electrodes were placed in an electric furnace, and annealed by allowing the furnace to come to $425^{\circ} \mathrm{C}$. and to return to room temperature, without opening the door of the furnace. Mercury was inserted into the re-

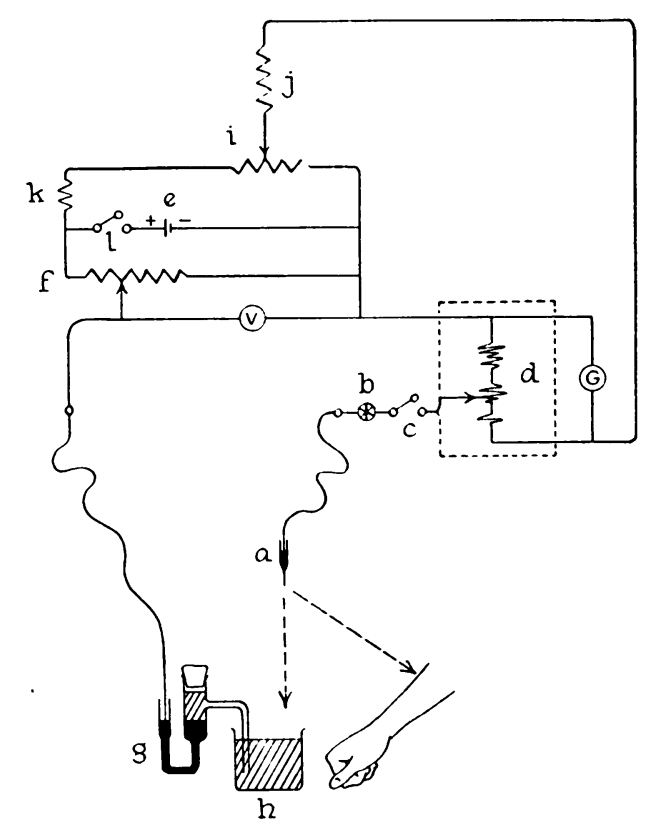

Fig. 1. Wiring Diagram of Circuit

(a) Electrode tip (cathode), (b) selector switch (controlling six electrodes), (c) electrode switch, (d) Ayrton Shunt (Rubicon No. 1243), (resistance 0 to $65,000 \mathrm{ohms}$ ), (e) dry cell (1.5 volts), (f) variable resistance $(10,000$ ohms), (g) calomel half-cell (anode), containing 0.90\% $\mathrm{NaCl}$, (h) $0.9 \% \mathrm{NaCl}$ in beaker, (i) variable resistance (500 ohms), (j) fixed resistance $(2,000,000 \mathrm{ohms}),(\mathrm{k})$ fixed resistance $(40,000 \mathrm{ohms})$, (1) main switch, (G) galvanometer (Rubicon No. 3418), (V) voltmeter.

maining section of tubing to complete the electrode. The tips of electrodes were kept in $0.9 \% \mathrm{NaCl}$ when not in use.

Figure 1 indicates the arrangement of the circuit. No. 18 insulated copper wire was used for all connections within the circuit except for that of electrode to selector switch, where No. 30 plain enameled wire was used. The variable resistance (i) was used to control the zero adjustment of the galvanometer. The main switch (1) was kept closed throughout all experiments. Figure 2 depicts the apparatus in use.

When the apparatus was being calibrated, the circuit was completed by the electrode tip (inserted in a small piece of human skin) and the salt bridge $(0.9 \% \mathrm{NaCl})$ of the calomel half-cell in the beaker. When the apparatus was used to measure $\mathrm{O}_{2}$, tension in intact skin the circuit was completed by the electrode in skin and by the salt bridge and the subject's finger in the beaker. With platinum electrodes of this size a very low current flows in either case (order of magnitude $10^{-7}$ amperes).

In oxygen free Ringer's solution the electrode gave no galvanometric deflections at voltages between $0.2 \mathrm{~V}$ and $0.8 \mathrm{~V}$. Above this voltage a precipitous rise in current occurred. In air equilibrated Ringer's solution deflections rose from 0 to 30 (Ayrton shunt at 10) at voltages be- 
tween $0.2 \mathrm{~V}$ and $0.8 \mathrm{~V}$. The considerable deflections and the relatively stable current at this voltage determined the choice of $0.6 \mathrm{~V}$ for all experimental work.

In order to avoid errors resulting from the period swing of the galvanometer and from excessive reduction of oxygen by prolonged current flow, in all experiments the galvanometer was read 10 seconds after closure of the electrode switch. Slightly lowered values were sometimes obtained when repeat readings were made every minute. Therefore, in all experiments at least two minutes were allowed to elapse betwecn readings. Even longer intervals were necessary when blood flow, and therefore oxygen supply, was much reduced, because reduction of oxygen at the electrode tip then became cumulative.

Calibration. Electrodes for use in skin cannot be calibrated by the simple expedient of measuring galvanometric deflections resulting from electrodes placed in solutions of known $\mathrm{O}_{2}$ tension. The deflections increase in proportion to the rate of supply of oxygen to the platinum, and this is greatly facilitated by the convection currents of a free solution. Furthermore, it is unlikely that the coefficient of oxygen solubility of any one fluid would

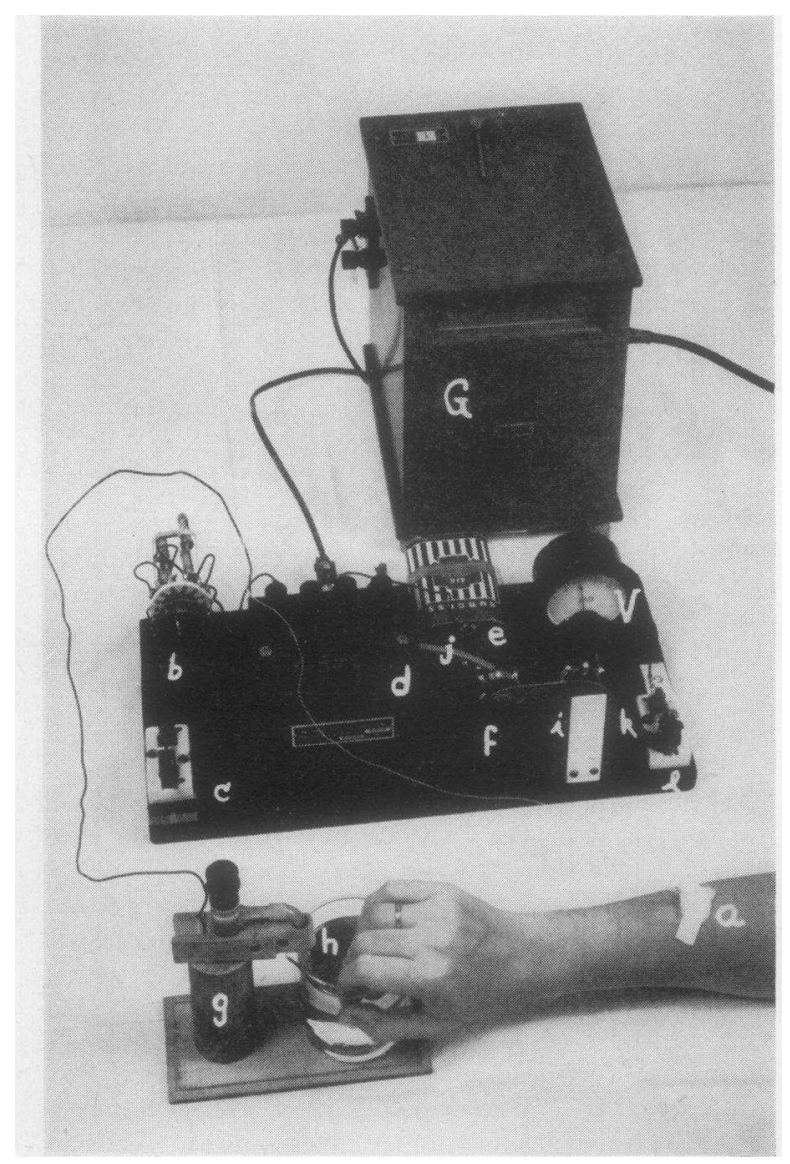

Fig. 2. Photograpil of Circuit

(For captions see Figure 1)

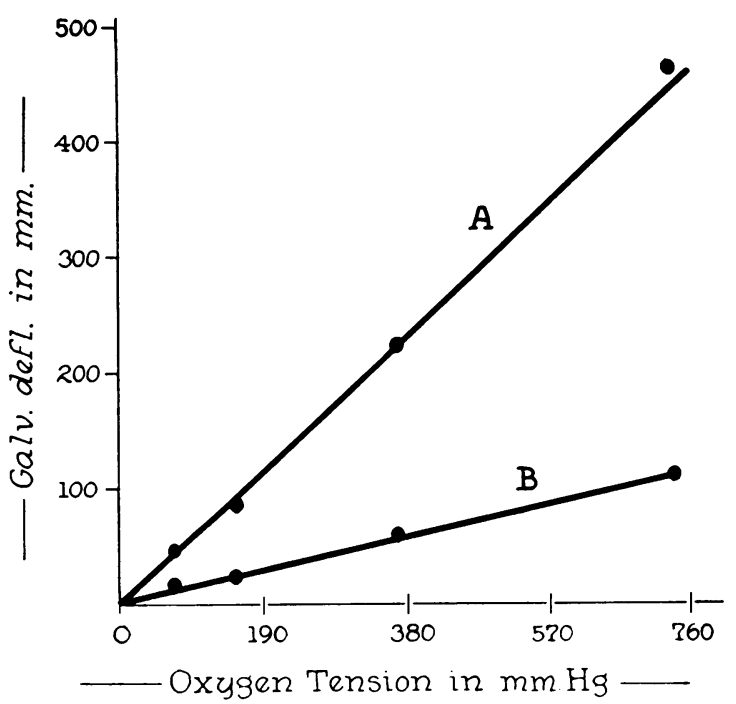

Fig. 3. Current-Oxygen Tension Relationship

Simultaneous measurements of current from (A) electrode tip (electrode No. 4) in $0.9 \% \mathrm{NaCl}$ and from (B) electrode tip (electrode No. 6) in excised, dead skin in $0.9 \% \mathrm{NaCl}$. Curves show effects upon current of various known tensions of oxygen in the saline. Correlation coefficient of points along $\mathrm{A}$ is 0.99 , along $\mathrm{B}$ is 0.98 . These characteristic differences in slope are only slightly influenced by the differences in the two electrodes. Temp. $23.5^{\circ} \pm 1^{\circ} \mathrm{C}$.

be identical with that of skin, or if it were, that the coefficients of oxygen diffusion would coincide. Trials of calibration from deflections obtained in free solutions yielded values of $\mathrm{O}_{2}$ tension in normal intact skin less than a third of that expected on the basis of known oxygen content of arterial blood. For use in intact skin it was necessary to calibrate the electrodes in dead, excised skin, in solutions of knozen oxygen tension.

The calibration technique consisted of equilibrating $0.9 \% \mathrm{NaCl}$ with room air at constant temperature, inserting the circuit-connected electrode tip at a $45^{\circ}$ angle 1.5 to $2.5 \mathrm{~mm}$. ( 1 to $2 \mathrm{~mm}$. vertically) into a small piece of dead skin (skin that has ceased to metabolize), placing the skin-tipped electrode and the circuit-connected saline bridge of the calomel half-cell in the saline, noting constant temperature of the saline, and taking galvanometric readings at two minute intervals until the deflections became constant (oxygen equilibrium between saline and skin, and the end of downward drift).

For the purpose of calibration, normal human skin was obtained from the surgical amphitheater, was kept in dry gauze for four hours at room temperature, its subcutaneous fat was removed, the remaining full thickness skin was cut into $3 \times 3 \mathrm{~mm}$. wedges, and these were quick-frozen and stored in an approximately sterile manner. Such skin gave little or no evidence of oxygen utilization. 
Correction factors. The relationships between known tensions of oxygen and their galvanometric deflections is given in Figure 3, both for electrodes free in $0.9 \% \mathrm{NaCl}$ (comparable to results of Davies and Brink), and for electrodes in dead skin in $0.9 \% \mathrm{NaCl}$. Straight lines were regularly produced as long as the temperature of the solution was kept constant. Variations in $\mathrm{NaCl}$ concentration between $0.9 \%$ and $2.0 \%$ had no effect. Variations in $\mathrm{pH}$ between 6.3 and 7.3, using phosphate buffer, had no effect. Wide variations in temperature of circuit junctions made of different metals had no effect. When the temperature of the solution was simply raised, markedly elevated deflections resulted, but when the saline after warming was re-equilibrated with oxygen, only moderately elevated deflections were produced. Throughout the reported studies each calibration was made at fixed temperature with saline and excised skin in oxygen equilibrium.

The effect of temperature near the electrode tip upon galvanometric deflections was systematically studied, and a correction factor for variations in temperature obtained. The temperature correction factor (i.e., temperature coefficient of the diffusion current) of our electrode depends, partly, upon the changing diffusibility of oxygen at changing temperature, and corresponds approximately to the value given by Kolthoff and Lingane (22) for other stationary platinum electrodes. Electrodes were inserted in excised, dead skin in $0.9 \% \mathrm{NaCl}$ equilibrated with air, and re-equilibrations were made at various temperatures between $1^{\circ} \mathrm{C}$. and $38^{\circ} \mathrm{C}$. Ample data for statistical analysis were obtained at temperatures in the neighborhood of $1^{\circ} \mathrm{C}$., $10^{\circ} \mathrm{C}$., $20^{\circ} \mathrm{C}$. and $30^{\circ} \mathrm{C}$., to express a straight line relationship between temperature and current with a correlation coefficient of .99 between $1^{\circ} \mathrm{C}$. and $30^{\circ} \mathrm{C}$. Sufficient data on equilibration at $37^{\circ} \mathrm{C}$. were obtained to allow extrapolation of the curve to this temperature. A graph for correcting current at one temperature, to

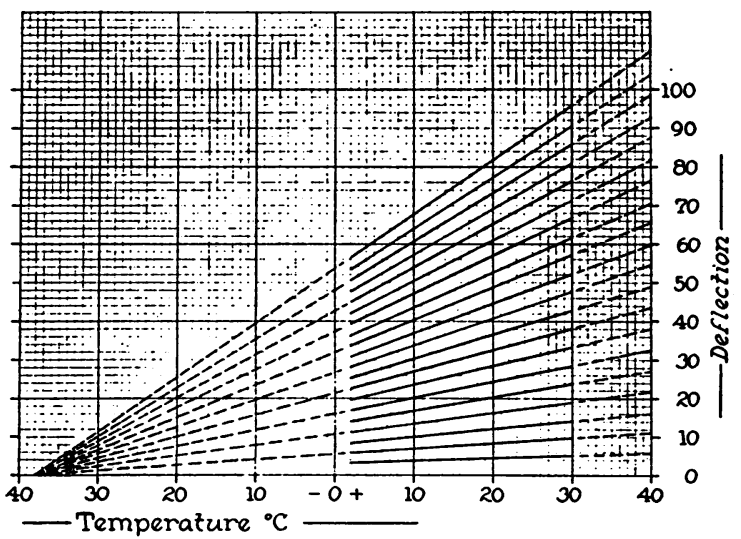

Fig. 4. Temperature Correction Chart

To correct (a), a galvanometric deflection taken at one temperature, to (b), the deflection expected at another temperature at the same oxygen tension, locate (a) and follow along line drawn through $\mathrm{V}$ (vanishing point of all lines), and read (b).
TABLE I

Standard deviations $(\sigma)$ and per cent standard deviations $(\sigma \%)$ of the galvanometric deflections of eight electrodes, within a single insertion in a piece of dead skin, and between different insertions in a piece of dead skin

\begin{tabular}{c|c|c|c|r|r|r|r}
\hline \hline $\begin{array}{c}\text { Elec- } \\
\text { trode }\end{array}$ & $\begin{array}{c}\text { Total } \\
\text { deter- } \\
\text { minations }\end{array}$ & $\begin{array}{c}\text { Total } \\
\text { inser- } \\
\text { tions }\end{array}$ & $\begin{array}{c}\text { Av. } \\
\text { deflec- } \\
\text { tion }\end{array}$ & \multicolumn{2}{|c|}{$\begin{array}{c}\text { Single } \\
\text { insertion }\end{array}$} & \multicolumn{2}{|c}{$\begin{array}{c}\text { Multiple } \\
\text { insertions }\end{array}$} \\
\cline { 5 - 8 } & & & & $\sigma$ & $\sigma \%$ & $\sigma$ & $\sigma \%$ \\
6 & 38 & 4 & 23.6 & 2.0 & 8.5 & 2.4 & 10.2 \\
8 & 47 & 9 & 31.8 & 3.2 & 10.1 & 15.7 & 49.3 \\
B & 15 & 4 & 34.0 & 2.9 & 8.5 & 3.0 & 8.8 \\
D & 16 & 4 & 25.5 & 2.0 & 7.8 & 6.6 & 25.9 \\
G & 21 & 5 & 25.2 & 2.7 & 10.7 & 5.8 & 23.0 \\
I & 26 & 5 & 26.4 & 2.7 & 10.2 & 7.2 & 27.3 \\
J & 13 & 3 & 26.0 & 2.8 & 10.8 & 6.5 & 25.0 \\
K & 13 & 3 & 29.7 & 3.1 & 10.4 & 14.5 & 48.8 \\
\hline
\end{tabular}

Skin in $0.9 \% \mathrm{NaCl}$ equilibrated with air. All deflections corrected for temperature.

current at any other temperature for the same $\mathrm{O}_{2}$ tension, in the range $1^{\circ} \mathrm{C}$. to $37^{\circ} \mathrm{C}$. was constructed from the data (Figure 4). All figures used for calculating $O_{\text {, }}$ tension in $\mathrm{mm}$. $\mathrm{Hg}$ were derived from data arbitrarily corrected to $20^{\circ} \mathrm{C}$.

Use of electrode in skin. The intact human skin was punctured with a 26 gauge hypodermic needle at an angle of $45^{\circ}$ to a depth of 2 to $3 \mathrm{~mm}$., well into the corium but short of the subcutaneous layer. The tip of the electrode, sterilized by boiling for five minutes, was inserted 1.5 to $2.5 \mathrm{~mm}$. into the opening made by the needle. Considerable experience was needed to avoid too superficial and too deep insertions. Low readings and sluggish changes were encountered in the former. The electrode was held at a $45^{\circ}$ angle by adhesive tape over it, and cotton below it. Pressure and traction at the electrode tip were avoided. Skin temperature was recorded from measurements by a thermocouple on the skin near the electrode.

Calculations. $\mathrm{O}_{2}$ tension of intact skin was calculated as follows: after correcting all galvanometric deflections to $20^{\circ} \mathrm{C}$., $\mathrm{O}_{2}$ tension in the excised, dead skin was taken as $.209 \times(760-32)=152$, where .209 is the proportion of oxygen in dry air, and 32 is the aqueous tension at $30^{\circ}$ C. 1 Then, $O_{2}$ tension of intact skin $=$ (corrected deflection in experiment/av. corrected deflection in calibrations) $\times$ $152 \mathrm{~mm}$. $\mathrm{Hg}$. When this method was used we obtained reasonable, if somewhat irregular values, averaging 87 $\mathrm{mm} . \mathrm{Hg} \mathrm{O}$ t tension, for skins having fast blood supplies. Some of the irregularities in the findings (Table II) are caused by variations of the electrodes (Table I), but some by varying amounts of oxygen penetrating different skins from the air (23).

Physiological procedures. Reflex vasoconstriction and vasodilatation were at first accomplished in a constant temperature room, by exposure of the body or by applying heating pads to the body. For quicker reflex effects a bath

${ }^{1} \mathrm{CO}_{2}$ of dead skin equilibrated against air is presumably negligible. Barometric pressure corrections are much smaller than errors inherent in the method. 
TABLE II

$\mathrm{O}_{2}$ lension of skin of normal subjects and of patients with peripheral arterial disease

Vasodilatation and vasoconstriction produced reflexly. For calibration characteristic of electrodes see Table I.

\begin{tabular}{|c|c|c|c|c|c|c|c|c|}
\hline \multirow[b]{2}{*}{ Normal, vasodilated } & \multirow[b]{2}{*}{$\begin{array}{l}\text { Subject } \\
\\
\\
\mathrm{Si} \\
\mathrm{We} \\
\mathrm{Sa} \\
\mathrm{Lo} \\
\mathrm{La} \\
\mathrm{Mo} \\
\mathrm{Mo} \\
\mathrm{St} \\
\mathrm{St} \\
\mathrm{Ja} \\
\mathrm{Fr}\end{array}$} & \multirow[b]{2}{*}{\begin{tabular}{l}
\multicolumn{1}{c}{ Part } \\
\\
Toe \\
Toe \\
Toe \\
Finger \\
Toe \\
Finger \\
Arm \\
Finger \\
Arm \\
Finger \\
Finger
\end{tabular}} & \multirow[b]{2}{*}{$\begin{array}{c}\begin{array}{c}\text { Electrode } \\
\text { No. }\end{array} \\
\\
6 \\
6 \\
8 \\
8 \\
8 \\
\text { D } \\
\text { B } \\
\text { D } \\
\text { B } \\
\text { D } \\
\text { D }\end{array}$} & \multirow[b]{2}{*}{$\begin{array}{c}\begin{array}{c}\text { Room } \\
\text { temp. }\end{array} \\
{ }^{\circ} \mathrm{C} . \\
21 \\
24 \\
26 \\
21 \\
23 \\
30 \\
\\
31 \\
30 \\
31\end{array}$} & \multirow[b]{2}{*}{$\begin{array}{c}\begin{array}{c}\text { Skin } \\
\text { temp. }\end{array} \\
{ }^{\circ} \mathrm{C} . \\
31 \\
29 \\
33 \\
33 \\
30 \\
34 \\
35 \\
\\
35 \\
35\end{array}$} & \multirow[b]{2}{*}{$\begin{array}{c}\text { Blood flow } \\
c c . / 100 c c . / \\
\text { min. } \\
40 \\
12 \\
26 \\
72 \\
20 \\
15 \\
20 \\
26 \\
20\end{array}$} & \multicolumn{2}{|c|}{$\underset{\text { breathing }}{\mathrm{PO}_{2}(\boldsymbol{m m})}$} \\
\hline & & & & & & & $\begin{array}{r}\text { air } \\
122 \\
93 \\
58 \\
71 \\
129 \\
150 \\
79 \\
56 \\
86 \\
60 \\
54\end{array}$ & $\begin{array}{c}\text { oxygen } \\
440 \\
\\
306 \\
395 \\
600 \\
445 \\
528 \\
604\end{array}$ \\
\hline \multicolumn{4}{|c|}{ Averages } & 26 & 33 & 28 & 87 & 474 \\
\hline Normal, vasoconstricted & $\begin{array}{l}\mathrm{Si} \\
\mathrm{We} \\
\mathrm{Lo} \\
\mathrm{Mo} \\
\mathrm{Ch} \\
\mathrm{Ja} \\
\mathrm{Fr} \\
\mathrm{Wi}\end{array}$ & $\begin{array}{l}\text { Toe } \\
\text { Toe } \\
\text { Finger } \\
\text { Finger } \\
\text { Finger } \\
\text { Finger } \\
\text { Finger } \\
\text { Finger }\end{array}$ & $\begin{array}{l}6 \\
6 \\
8 \\
\text { D } \\
\text { D } \\
\text { D } \\
\text { D } \\
\text { D }\end{array}$ & $\begin{array}{l}19 \\
22 \\
20 \\
30 \\
31 \\
28 \\
29 \\
29\end{array}$ & $\begin{array}{l}21 \\
22 \\
22 \\
30 \\
31 \\
29 \\
29 \\
29\end{array}$ & $\begin{array}{l}6 \\
2 \\
5 \\
1 \\
1 \\
2 \\
1 \\
1\end{array}$ & $\begin{array}{l}51 \\
44 \\
18 \\
18 \\
60 \\
12 \\
15 \\
54\end{array}$ & $\begin{array}{l}354 \\
336 \\
270 \\
312 \\
198\end{array}$ \\
\hline \multicolumn{4}{|c|}{ Averages } & 26 & 27 & 2 & 34 & 294 \\
\hline $\begin{array}{l}\text { Arterial occlusion } \\
\text { vasodilated }\end{array}$ & $\begin{array}{l}\mathrm{La} \\
\mathrm{Ka} \\
\mathrm{Le} \\
\mathrm{Le} \\
\mathrm{Do} \\
\mathrm{Ma}\end{array}$ & $\begin{array}{l}\text { Toe } \\
\text { Toe } \\
\text { Toe } \\
\text { Toe } \\
\text { Toe } \\
\text { Toe }\end{array}$ & $\begin{array}{l}8 \\
8 \\
8 \\
8 \\
8 \\
6\end{array}$ & $\begin{array}{l}23 \\
23 \\
22 \\
23 \\
21 \\
24\end{array}$ & $\begin{array}{l}26 \\
26 \\
26 \\
28 \\
25 \\
30\end{array}$ & $\begin{array}{r}6 \\
6 \\
8 \\
11 \\
7 \\
16\end{array}$ & $\begin{array}{r}5 \\
35 \\
17 \\
6 \\
22 \\
27\end{array}$ & $\begin{array}{l}72 \\
49\end{array}$ \\
\hline \multicolumn{4}{|c|}{ Averages } & 23 & 27 & 9 & 19 & \\
\hline $\begin{array}{l}\text { Arterial occlusion } \\
\text { vasoconstricted }\end{array}$ & $\mathrm{Su}$ & Toe & & 26 & 25 & 1 & 10 & 18 \\
\hline
\end{tabular}

tub was used, but with this it was not feasible to control environmental air temperature closely. Direct cooling of an extremity (hand) was accomplished by covering it with large ice flakes, rather than with cold water, in order to avoid undue moisture at the junction of electrode and skin.

Oxygen mixtures for inhalation were employed at fast rates of delivery through a distended rubber bag and close-fitting mask.

Blood flow was calculated as cc. of blood per 100 cc. of digit per minute from measurements, at known room temperatures, of the temperature of the surface of the skin near each electrode (21). Valid calculations were made in all of the studies except those in which direct cooling of the extremity was employed. The measurements of skin temperature were also used in calculating $\mathrm{O}_{2}$ tension of skin from the galvanometric deflections since intracutaneous temperature is usually only about $1^{\circ} \mathrm{C}$. higher than skin surface temperature.

Sources of error. Several correctable sources of error in the use of the electrode were encountered. The down- ward drift of readings was usually minimal within less than a half hour after the insertion of the electrode. Local erythema and local wheal formation at the electrode tip were rare and easily avoided. A droplet of blood at the electrode tip made the reading inaccurate. A blood droplet with its large volume to surface ratio could not take up, or give off, oxygen as readily as cells did. The droplet was detected when the circulation was arrested or oxygen breathed, for then galvanometric deflections changed more slowly than normally, and there was further confirmation on withdrawing the electrode. The error was corrected by reinserting the electrode elsewhere. Errors having to do with varying thickness of skin, and with varying depth of electrode, sometimes required reinsertion for correction. These errors are lessened by keeping the electrode tips at depths 1.5 to $2 \mathrm{~mm}$. (24). Further study is in progress. In closing the electrode switch, the galvanometric deflection was sometimes distorted unless the finger was promptly withdrawn from the switch. Occasionally, on very damp days there were fluctuations in current which were prevented by drying 
the wires or by drying the wire-mercury contacts in the electrodes.

The errors resulting from reinsertions (see Table I) can be minimized by the use of several electrodes. Study of reinsertion variation in electrodes is being continued. With changing circulations there are changes in distances from hemoglobin to electrode as capillaries open and close. This must result in changing oxygen gradients which to some degree affect the current which is measured, and the oxygen tension which is calculated from it.

\section{RESULTS}

Excised skin. The electrode was first tested for stability upon reinsertion into excised, dead skin. Unfortunately, in many instances, both in the case of the skin-tipped electrodes and of the free-tip electrodes, constant calibrations were not obtained (Table I). In both, the average reinsertion variation was about $25 \%$, as compared with $15 \%$ day-today variations of such electrodes in solutions (2). Lacking a circulation, and having a slow supply of oxygen, excised skin sometimes required that measurements be made at longer intervals than two minutes.

Freshly excised skin gave zero values when in solutions having the same $\mathrm{O}_{2}$ tension as air, presumably because it metabolized. Such skin became satisfactory for calibrations when later it ceased to metabolize, and galvanometric readings increased and then became constant. When greater $\mathrm{O}_{2}$ tensions than that in air existed in the solutions, some oxygen penetrated the skin to the tip of the electrode. Whether this would occur in especially freshly prepared specimens, with most active metabolism, has not been determined. Passivity of the skin to oxygen in room air appears to denote death of skin, or at least inability of skin to metabolize. More extensive studies are being made of $\mathrm{O}_{2}$ tension in excised skin under various conditions (25).

Intact skin. When cutaneous blood flow was fairly high, with some 20 to $70 \mathrm{cc}$. of blood flowing per $100 \mathrm{cc}$. of tissue per minute, the $\mathrm{O}_{2}$ tension of skin was usually in the region of 70 to $120 \mathrm{~mm}$. $\mathrm{Hg}$, approximately that of the arterial blood supplying it. When cutaneous blood flow was reduced by reflex vasoconstriction to $2 \mathrm{cc}$. per 100 cc. per minute, the $\mathrm{O}_{2}$ tension of the skin was in some cases as little as $15 \mathrm{~mm}$. $\mathrm{Hg}$, a small fraction of the $\mathrm{O}_{2}$ tension of the blood supplying it (Table II). When slow cutaneous blood flows changed to somewhat faster blood flows, great increases in the $\mathrm{O}_{2}$ tension of skin resulted (Figure 5). When medium cutaneous blood flow increased by the same absolute amount much less increase in $\mathrm{O}_{2}$ tension of skin occurred.

The lowest $\mathrm{O}_{2}$ tension found in skin having normal vessels resulted from sufficient direct cooling of the extremity to elicit the red hand that Lewis (26) described as having a very slow circulation. The slowed circulation and inability of hemoglobin to give up its oxygen at low temperatures $(27,28)$
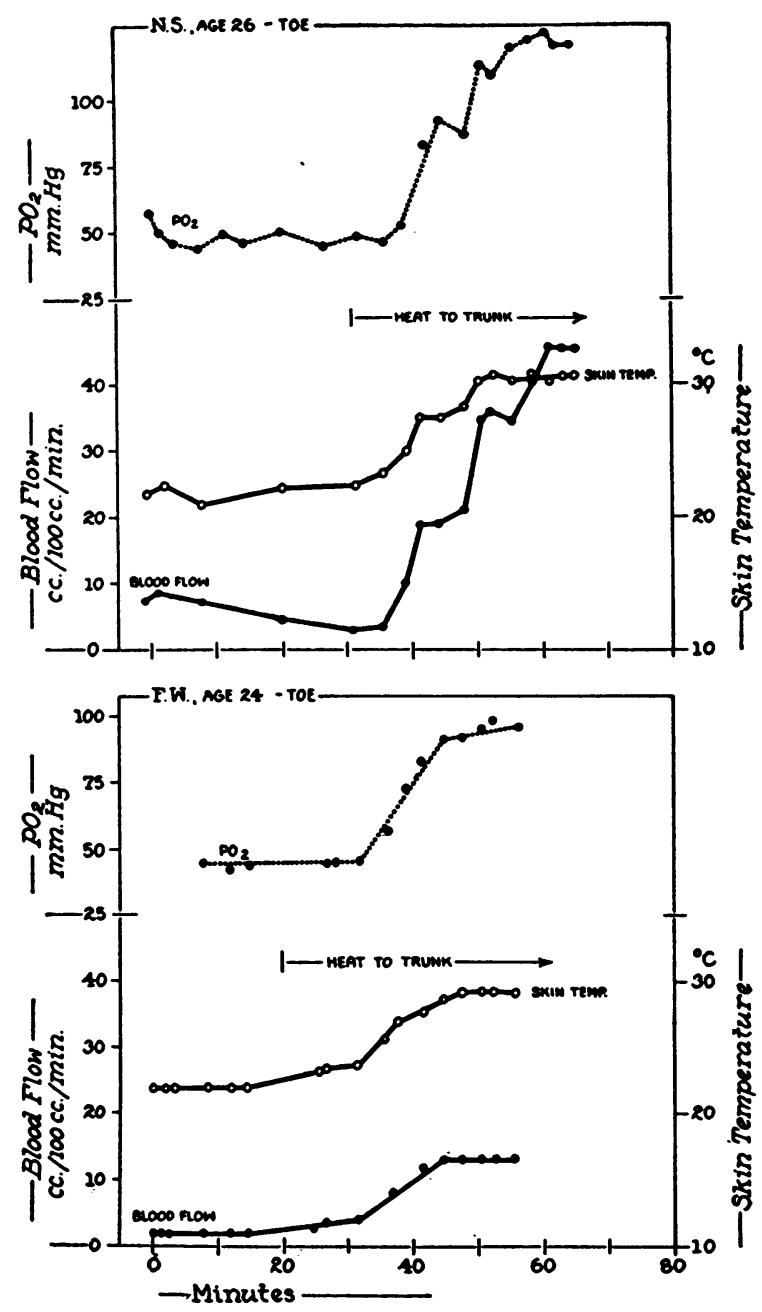

Fig. 5. Effect of Physiological Variations in Blood Flow Upon Oxygen Tension of Skin of ToE

Electrode No. 6: (for its calibration characteristics see Table I). Two normal female subjects, N. S. (upper graph) and F. W. (lower graph). Blood flow through skin of toe was increased reflexly by heating pads on the body. Blood flow in toe was derived from measurements of skin temperature (19). 
predominated over the lowered metabolism, and skin tissue became depleted of oxygen.

The experiments of Hodes and Larrabee (19) were repeated and confirmed, showing an increase in oxygen in the skin of the arm resulting from breathing oxygen and a decrease resulting from the arrest of the circulation by pressure cuff. Figure 6 shows such results plotted as $\mathrm{O}_{2}$ tension in $\mathrm{mm} . \mathrm{Hg}$. Breathing $100 \%$ oxygen caused large increases in $\mathrm{O}_{2}$ tension of skin in all cases in which there was no severe disease of the vessels. The largest increases from oxygen inhalation resulted when the skin had a rapid circulation (Table II). Oxygen tension at the peak of oxygen inhalation was usually between 400 and $600 \mathrm{~mm}$. $\mathrm{Hg}$. The increment in $\mathrm{O}_{2}$ tension was, on the average, about the same as the increment in the oxygen breathed, giving further evidence that fast circulations through the skin are greatly in excess of those needed for skin metabolism. In the case of severe vasoconstriction by direct or reflex chilling, $\mathrm{O}_{2}$ tension of skin was about $10 \mathrm{~mm}$. $\mathrm{Hg}$ (data not tabulated). Oxygen inhalation usually raised this level to between 200 and $400 \mathrm{~mm}$. $\mathrm{Hg}$. The increase resulting from oxygen inhalation was usually greater in the case of direct chilling, probably because of a lower metabolism, than in reflex vasoconstriction.

When the circulation was arrested by an arm cuff inflated above systolic blood pressure, some 15 to 25 minutes were required to allow $\mathrm{O}_{2}$ tension of skin to decrease to zero if no attempt was made to exclude the blood from the small vessels near the tip of the electrode. With the progress of time the rate of decrease in $\mathrm{O}_{2}$ tension declined. The declining rate demonstrates a slowing of metabolism of skin at lower $\mathrm{O}_{2}$ tensions, in keeping with the studies of some cells and tissues in the Warburg apparatus, cited by Kempner (29). An example of the effect of circulatory arrest is portrayed in Figure 6.

Another technique is probably more satisfactory in estimating metabolism in skin. Blanching of the skin some $5 \mathrm{~mm}$. in diameter around the elec-

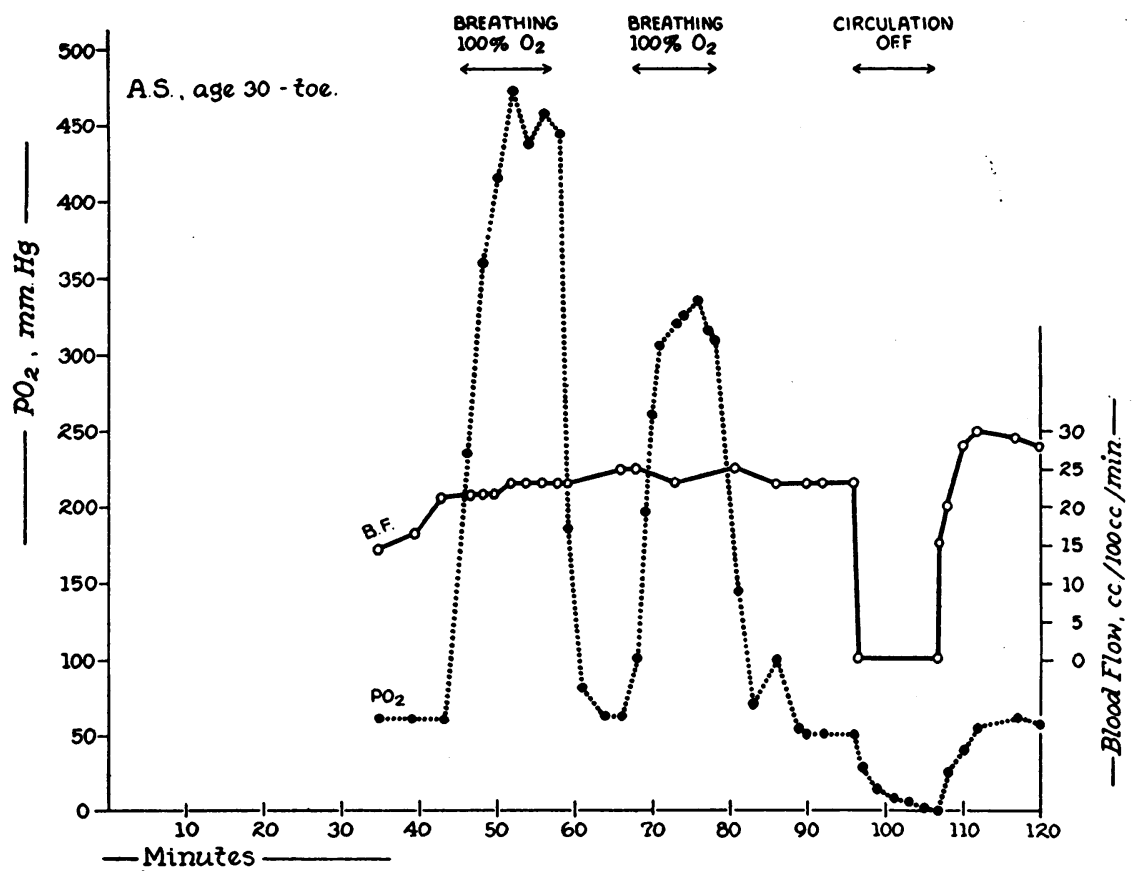

Fig. 6. Effects of Oxygen Inhalation and of Arrest of Circulation on OXYgen Tension OF Skin of ToE

Electrode No. 8: (for its calibration characteristics see Table I). Oxygen given by open mask at rate of 15 liters per minute to a normal female. Circulation arrested by blood pressure cuff on lower leg, with pressure $50 \mathrm{~mm}$. above systolic. Blood flow in toe derived from measurements of skin temperature of toe (19). 
trode tip is accomplished by raising and advancing the electrode. Then the $\mathrm{O}_{2}$ tension becomes zero within one to two minutes. This short time allows little influence from oxygen in the surrounding air. The rapid decrease in $\mathrm{O}_{2}$ tension of blanched skin, as compared with that of skin having blood in its capillaries, demonstrates the much lower oxygen storing capacity of hemoglobin-free tissues. To derive metabolism, in volumes $\mathrm{O}_{2}$ per volume of skin per unit of time, from $\mathrm{O}_{2}$ tension of skin containing no hemoglobin, requires only an analysis of the oxygen content of bloodless skin at one known $\mathrm{O}_{2}$ tension.

Skin of extremities having diseased blood vessels had reduced $\mathrm{O}_{2}$ tension (Table II). The $\mathrm{O}_{2}$ tension of skin in hands and feet having occluded arteries, increased with vasodilatation less than was the case in normal subjects, except when a collateral blood supply was excellent. In occlusive vascular disease, as well as in normal limbs, lowered oxygen tension in skin can be the result of vasoconstriction. For this reason it was necessary to cause vasodilatation and again measure the $\mathrm{O}_{2}$ tension of skin, before concluding that low values resulted from arterial occlusion. When this was done the clinical impression of severe arterial occlusion was as well supported by finding low oxygen tensions as by measurement of skin temperature changes.

The $\mathrm{O}_{2}$ tension of extremely ischaemic skin, such as that resulting from massive arterial occlusion, yielded information of clinical importance which has not been previously available. A patient with rheumatic heart disease and auricular fibrillation was seen three days after embolism of a common iliac artery. The ischaemic limb was anesthetic up to the knee, but there was no gangrene, bulla, or obvious drying, and its color was pink in most areas and only mildly cyanotic in others. The $\mathrm{O}_{2}$ tension of skin of the foot was approximately that of room air, and decreased at ascending levels, on the limb. Breathing oxygen failed to change the $\mathrm{O}_{2}$ tension of skin of foot or lower leg, but increased that of the upper leg. We concluded that the skin of the lower leg, and probably the underlying tissues, had lost all capacity to metabolize. The leg was amputated and its gray muscle extending nearly to the hip confirmed our conclusion of widespread death of tis- sue. Shortly thereafter the problem of a second such patient was clarified by similar measurements.

\section{DISCUSSION}

To what extent measurements can be said to be of intra- or extracellular oxygen tension we cannot say. Oxygen in the thin layer of fluid between electrode and the partly broken cells is probably being measured, and the $\mathrm{O}_{2}$ tension of this layer results from the circulation rate, the rate of diffusion from capillaries to cells, the rate of diffusion of oxygen from the air into the skin, the rate of utilization of oxygen by the cells, and the rate of diffusion from the cells to the layer in contact with the electrode. In a sense the $\mathrm{O}_{2}$ tension that is measured is the availability of oxygen to cells.

Several observations show that measurements were of $\mathrm{O}_{2}$ tension in the tissue of skin and not of the blood in cutaneous vessels. Erratic values were obtained when the tip of the electrode was in blood, but theoretical values for $\mathrm{O}_{2}$ tension of skin were obtained when no blood could be extruded from the puncture hole. Bloodless, excised, dead skin equilibrated against air yielded values as much higher than those of intact skin having a fast circulation, as the $\mathrm{O}_{2}$ tension of air is greater than the calculated $\mathrm{O}_{2}$ tension of the arterial blood in skin. In the skin of the warm extremity the $\mathrm{O}_{2}$ tension decreased only slowly after sudden arrest of the circulation, and became zero when the skin was deeply cyanotic after 25 minutes. Two seconds after re-establishing the circulation the skin became bright red as the result of the rapid inflow of arterial blood, but at that moment the $\mathrm{O}_{2}$ tension was as low as it had been during the end of the arrest period. Sixty seconds were required to establish the $\mathrm{O}_{2}$ tension of the pre-experimental period. Thus it seems clear that skin tissue oxygen, rather than blood oxygen, was measured, though the two closely approximate when the circulation is rapid.

One has to expect that the $\mathrm{O}_{2}$ tension of intact skin having a fast blood supply roughly approximates that of blood in large arteries $(100 \mathrm{~mm}$. $\mathrm{Hg}$ ), for fast blood flows to skin are greatly in excess of metabolic needs, since such flows are designed for the greater task of eliminating body heat. How much this blood flow is in excess of that needed for metabolism is shown by the fact 
that 2 to 5 cc. of blood per 100 cc. of skin per minute are adequate for nutrition of skin, whereas flows of $100 \mathrm{cc}$. are common during elimination of excesses of body heat $(21,30)$. That skin $\mathrm{O}_{2}$ tension at fast blood flows reflects arterial oxygen tension is shown by the great increases in skin $\mathrm{O}_{2}$ tension when oxygen is inhaled. However, skin $\mathrm{O}_{2}$ tension is not expected to be identical with arterial oxygen tension for at least three reasons. The cells consume at least a little of the oxygen. Some oxygen penetrates from the surrounding air (23). Oxygen tension of skin having a fast blood flow was found, on occasion, to be $20 \mathrm{~mm}$. Hg lower when the limb was in nitrogen rather than in air. The fact that the temperature in the minute vessels of skin is lower than in large arteries depresses the dissociation of oxygen from hemoglobin. Measurements taken from the $\mathrm{O}_{2}$ dissociation curves of Brown and Hill, at $95 \%$ oxygen saturation, show that this decrease amounts to some $15 \mathrm{~mm} . \mathrm{O}_{2}$ tension when the temperature decreases from $37^{\circ}$ to $34^{\circ} \mathrm{C}$. (27). The increase in oxygen of skin which accompanies an increasing skin temperature (Figure 5) results mainly from the faster supply of oxygen to cells by reason of the faster circulation, but also from the greater diffusibility of oxygen, and from the greater dissociation of oxygen from hemoglobin at increased temperature.

The method can be applied to a number of studies in the field of peripheral vascular disease, including the clinical usefulness of oxygen inhalation and of heat and cold upon ischaemic extremities. One can now only speculate upon possibilities of new therapeutic uses for oxygen inhalation, perhaps in conjunction with direct cooling, in some cases, to lessen metabolism, or with direct warming, in others, to increase oxygen dissociation and diffusibility.

The method lends itself to other studies, two of the most important being estimations of arterial oxygen tension by measurements in warm skin and estimations of metabolism of skin. Conventional measurements of arterial oxygen tension are difficult, and require arterial sampling. The oximeter requires an arterial puncture for calibration and fails to operate beyond the limits of the oxygen dissociation curve. The skin oxygen tension method offers an opportunity to explore intra-arterial oxygen above and beyond the confines of the oxygen dissociation curve. At tensions above $100 \mathrm{~mm}$. the skin electrode is useful in clinical estimates of blood oxygen tension. Current unpublished experiments on patients with right-to-left pulmonary shunts show that oxygen inhalation results in a minimal rise in skin oxygen tension (31).

We have made some preliminary experiments on metabolism in intact skin. One way to estimate metabolism of skin is to measure the decrease of $\mathrm{O}_{2}$ tension in the skin of a limb after arresting the circulation by means of a blood pressure cuff inflated above systolic blood pressure (Figure 6). The rate of decrease of $\mathrm{O}_{2}$ tension is a function of metabolism of skin, and the procedure has the advantage of simplicity, but it has disadvantages. One results from doubt concerning total arrest of the circulation by such compression, though blood flow through bone is said to be extremely small (32). Another disadvantage is a lack of exact information regarding the penetration of oxygen from air into different skins, and into skin at different $\mathrm{O}_{2}$ tensions. There is also the disadvantage of blood in small vessels acting as variable oxygen stores for the skin. When the venous blood in the extremity is allowed to escape by elevating the extremity and applying the cuff pressure rapidly, the average time of exhaustion of all oxygen from the skin is 15 minutes. When more blood is trapped in the extremity by depressing the extremity and applying the cuff slowly, the average time of exhaustion of all oxygen from the skin is 25 minutes. Furthermore, in skin containing hemoglobin, there is the disadvantage that the derivation of oxygen volumes from $\mathrm{O}_{2}$ tension would require measurement of $\mathrm{CO}_{2}$ as well as of temperature and hemoglobin, because of the effects of these two factors upon the oxygen dissociation curve.

These disadvantages are circumvented by avoiding the use of a pressure cuff, and substituting for it the procedure of raising and advancing the tip of the electrode. The disadvantage of estimating metabolism by this blanching technique lies in the fact that repeated blanchings produce a somewhat irregular curve of decreasing $\mathrm{O}_{2}$ tension, either because of movement of the electrode tip, or because of cumulative damage to the skin at the tip 
of the electrode. Some other method of blanching the skin may prove advisable, but none that we have tried has produced as rapid a drop in $\mathrm{O}_{2}$ tension of skin.

\section{SUMMARY}

1. A method is presented for making rapid estimations of oxygen tension in intact human skin. It depends upon use of a platinum electrode inserted into the skin to measure electrical current.

2. The electrode is calibrated by inserting it into excised, dead skin immersed in solutions of varying, known oxygen tensions. When calculated corrections for temperature variations are applied, current varies directly with oxygen tension in the solution.

3. The method is highly sensitive during a single insertion into skin, and is roughly quantitative over a number of insertions.

4. Evidence is presented that the method measures oxygen tension of skin tissue and not of blood.

5. Measurements of oxygen tension of normal, intact, living skin of the extremities during conspicuous cutaneous vasodilatation approximate the theoretical value for oxygen tension of such skin. Oxygen tension of the skin greatly diminishes during cutaneous vasoconstriction induced either directly or reflexly by cold.

6. In normal individuals, inhalation of oxygen mixtures ranging from $10 \%$ to $100 \%$ changes the oxygen tension of the vasodilated skin of the extremities approximately in proportion to the concentration in the inhaled mixture. Oxygen tensions of skin during vasoconstriction are raised by inhaling $100 \%$ oxygen, but not to the levels achieved during vasodilatation.

7. The low oxygen tension in the skin of extremities made severely ischaemic by occlusive arterial disease is moderately increased by oxygen inhalation.

8. A means of estimating the rate of utilization of oxygen by intact skin is described.

9. Small pieces of freshly excised skin in $0.9 \%$ $\mathrm{NaCl}$ equilibrated with air have zero oxygen tension, presumably because of metabolism without circulation. As "death" of skin supervenes, oxygen tension approximates that of air.

10. Death of intact skin of a limb is strongly suggested when its oxygen tension approximates that of air and is not influenced by oxygen inhalation.

\section{ACKNOWLEDGMENT}

We wish to acknowledge technical aid given us by Mrs. John G. Williams, and advice given us by many members of the Eldridge Reeves Johnson Foundation for Medical Physics and by Mr. George Peirce.

The work was made possible by grants from the Life Insurance Fund for Medical Research and the U. S. Public Health Service.

\section{BIBLIOGRAPHY}

1. Starr, I., Jr., On the use of heat, desiccation and oxygen in the local treatment of advanced peripheral vascular disease. Am. J. M. Sc., 1934, 187, 498.

2. Davies, P. W., and Brink, F., Jr., Microelectrodes for measuring oxygen tension in animal tissues. Rev. Scient. Instruments, 1942, 13, 524.

3. Pflüger, E., Die Gase der Secrete. Arch. f. d. ges. Physiol., 1869, 2, 156.

4. Strassburg, G., Die Topographie der Gasspannungen im thierischen Organismus. Arch. f. d. ges. Physiol., 1872, 6, 65.

5. Krogh, A., Some new methods for the tonometric determination of gas-tensions in fluids. Skandinav. Arch. f. Physiol., 1908, 20, 259.

6. Krogh, A., On micro-analysis of gases. Skandinav. Arch. f. Physiol., 1908, 20, 279.

7. Verzár, F., The influence of lack of oxygen on tissue respiration. J. Physiol., 1912, 45, 39.

8. Pietro, S. di, Mode de se comporter gaz (O. $\mathrm{CO}_{2}$. Az. $H$.) injectés dans l'abdomen d'animaux vivants et d'animaux morts. Arch. ital. de Biol., 1902, 38, 102.

9. Tobiesen, F., Die Zusammensetzung der Pneumothoraxluft. Deutsches Arch. f. klin. Med., 1914, 115, 399.

10. Campbell, J. A., Gas tensions in the tissues. Physiol. Rev., 1931, 11, 1.

11. Danneel, von $H$., Uber den durch diffundierende Gase hervorgerufenen Reststrom. Zeitschr. f. Electrochemie, 1897, 4, 227.

12. Salomon, von E., Theorie des Reststromes den man bei polarisierten Elektroden beobachtet. Zeitschr. f. physik. Chemie., 1897, 24, 55.

13. Cottrell, F. G., Der Reststrom bei galvanischer Polarisation, betrachtet als ein Diffusionsproblem. Zeitschr. f. physik. Chemie., 1903, 42, 385.

14. Grassi, U., Zur Theorie des Reststromes. Zeitschr. f. physik. Chemie., 1903, 44, 460.

15. Nernst, W., and Merriam, E. S., Zur Theorie des Reststromes. Zeitschr. f. physik. Chemie., 1905, $53,235$. 
16. Blinks, L. R., and Skow, R. K., The time course of photosynthesis as shown by a rapid electrode method for oxygen. Proc. Nat. Acad. Sci., 1938, 24, 420.

17. Davis, E. W., McCulloch, W. S., and Roseman, E., Rapid changes in the $\mathrm{O}_{2}$ tension of cerebral cortex during induced convulsions. Am. J. Psychiat., 1944, 100, 825.

18. Davies, P. W., and Rémond, A., Oxygen consumption of the cerebral cortex of the cat during metrazol convulsions. A. Research Nerv. \& Ment. Dis., Proc., 1946, 26, 205.

19. Hodes, R., and Larrabee, M. G., Personal communication.

20. Montgomery, H., and Horwitz, O., Oxygen tension in the skin of extremities. J. Clin. Invest., 1948, 27, 550.

21. Montgomery, H., Naide, M., and Freeman, N. E., The significance of diagnostic tests in the study of peripheral vascular disease. Am. Heart J., 1941, 21, 780.

22. Kolthoff, I. M., and Lingane, J. J., Polarography. Polarographic Analysis and Voltammetry Amperometric Titrations. Interscience Publishers, Inc., New York, 1941.

23. Shaw, L. A., Messer, A. C., and Weiss, S., Cutaneous respiration in man. I. Factors affecting the rate of carbon dioxide elimination and oxygen absorption. Am. J. Physiol., 1929, 90, 107.
24. Urbach, F., Personal communication.

25. Brown, R. B., Personal communication.

26. Lewis, T., The Blood Vessels of Human Skin and Their Responses. Shaw \& Sons, Ltd., London, 1927, p. 143.

27. Brown, W. E. L., and Hill, A. V., The oxygendissociation curve of blood, and its thermodynamical basis. Proc. Roy. Soc. London, 1923, B94, 297.

28. Goldschmidt, S., and Light, A. B., The effect of local temperature upon the peripheral circulation and metabolism of tissues as revealed by the gaseous content of venous blood. Am. J. Physiol., 1925, 73, 146.

29. Kempner, W., The role of oxygen tension in biological oxidations. Symposia in Quantitative Biology, 1939, 7, 269.

30. Burton, A. C., The range and variability of the blood flow in the human fingers and the vasomotor regulation of body temperature. Am. J. Physiol., 1939, 127, 437.

31. Montgomery, H., Zinsser, H. F., and Horwitz, O., Oxygen tension of tissues by the polarographic method. II. Detection of right to left shunts by changes in skin oxygen tension resulting from inhalation of oxygen. Circulation, in press.

32. Wolf, E. P., Local changes of colour in the skin deprived of its normal blood supply; with remarks on local asphyxia. Heart, 1924, 11, 327.

\section{SPECIAL NOTICE TO SUBSCRIBERS}

Post Offices will no longer forward the Journal when you move.

Please notify Journal of Clinical Investigation, Business Office, c/o Cincinnati General Hospital, Cincinnati 29, Ohio, at once when you have a change of address and do not omit the zone number if there is one. 